\title{
Economic migration and challenges in an emerging Eastern European destination country: evidence about immigrant labor market integration in Romania
}

\author{
Ovidiu Oltean $^{1 *}$, Georgiana Găvruș ${ }^{1}$ \\ ${ }_{1}$ Babeș-Bolyai University of Cluj-Napoca, Department of Political Sciences, 71 Moșoiu, 400132 Cluj-Napoca, \\ Romania
}

KEYWORDS

Immigrant integration

Emerging immigrant

destinations

Labor market integration

Patterns of integration

Legal status

\begin{abstract}
A BSTRACT
In this paper we aim to investigate the effects and outcomes of the integration system and reveal through data analysis the experiences of immigrants coming to Romania. Traditionally a country of emigration, Romania is becoming an emerging immigrant destination, with people coming from countries like Nepal, Vietnam, China. The study relies on a data set collected in two stages in 2017 ( $\mathrm{N}=537)$ and 2018 ( $\mathrm{N}=645)$, amongst immigrants residing in Romania. Measures of labor market integration were analysed from a multidimensional perspective, mapping out patterns of integration as well as the experiences and challenges faced by the newcomers in their attempt to obtain a satisfactory employment status. The results indicate that Romania is becoming an emerging immigration destination, experiencing a steady increase and diversification of immigration flow. In 2018, the number of those that come here to work exceeded the number of those that came to study, representing the second most important reason of entry after those who came for family reunion (IGI 2018).
\end{abstract}

\section{Introduction}

Romanian economy is growing more complex and larger while continuously facing out-migration and structural labor-supply imbalances. The labor

\footnotetext{
* Contact address: ovidiuoltean@fspac.ro (O. Oltean)
} 
shortage has increased significantly in the past years contributing to mounting pressure for employers to increase salaries, making the labor force in Romania scarcer and more expensive to hire (INCE and KPMG 2019). This has led to the situation of employers recruiting laborers abroad while national authorities have relaxed the legislation allowing the employment of third country nationals (Florea 2019; Derscariu and Vechiu 2018). Such developments follow the pattern of other Central and Eastern European countries which turned after the accession to the European Union and ensuing economic development from emigration source countries to transit and destination countries (Drbohlav 2012; Górny et al. 2009; Drbohlav, Hárs and Grabowska-Lusińska 2009).

Countries such as the Czech Republic, Hungary and Poland have emerged in the past decade as immigrant destinations due to their sustained modernization, economic development and political stability (Pawlak 2015; Drbohlav 2012). After decades of outmigration and economic stagnation, the democratization of these countries and integration into the European and global marked led to increased investments, opening of new production facilities and upgrading of industrial capacities and production outputs (Pavlínek, Domański and Guzik 2009). This has generated in consequence a surplus of available jobs and work force shortages. To supply this shortage, these countries have started to outsource laborers abroad (Alderman 2017). They have attracted mostly migratory flows originating in countries outside the European Union, composed mainly of temporary economic migrants coming from Ukraine and Russia, and migrant groups originating from China and Vietnam (Grzymała-Kazłowska 2015; Janská, Čermák and Wright 2014). These workers are employed mainly in the manufacturing sector and construction services, with only a few occupying highly skilled positions (Drbohlav 2012).

Although Romania had a slower transition to democracy and development of a free market economy in comparison to its Central-Eastern European neighbors, due to the sustained pace of economic growth of the past years and economic modernization, coupled with a continuous emigration of the active labor force, it has come to face similar problems like Czech Republic, Hungary and Poland. Thus, it has turned in the past years towards temporary labor recruitment, looking for welders, construction specialists, 
agriculture workers and personnel for the hospitality industry in countries that previously had not history of emigration to Romania, like Vietnam, Philippines and Nepal (Poșirca 2017). These labor mobility flows add up to other types of migratory flows fueling the growth of foreign nationals entering Romania. Although these population flows contribute to the supply of available jobs and to the maintenance of the current pace of economic growth, they pose unprecedented challenges. Neither Romania nor the other Central and Eastern European countries have experience in immigrant integration (Cosciug et al. forthcoming; Cosciug et al. 2017; GrzymałaKazłowska 2015; Janská, Čermák and Wright 2014). While Czech Republic and Poland have done some efforts in this direction, Romania seems to be little prepared to manage this newly developing migratory stream. The institutional immigrant integration capacity is underdeveloped, most of Romanian public institutions having little experience in migrant integration, and, although immigrant integration has made its way on the public agenda in the past years, there is still insignificant data on this topic (Cosciug et al. 2017; Coşciug et al forthcoming).

Following these recent developments, this research attempts to fill in the gap of immigrant integration accounts by analyzing immigrants' work experiences on the Romanian labor market. We try to illustrate the challenges and experiences that immigrants face in Romania in their search for employment and in their struggles to secure a decent income. We build our analysis on a data set collected in two stages, during 2017 and 2018. The data was collected at a national level, through stratified random sampling, and covers four main immigrant categories. We aim to outline the effects and outcomes of the integration system and reveal through data analysis the experiences of immigrants coming to Romania.

The paper proceeds as follows. In the following section we briefly describe the immigration context in Romania. In the second section we discuss the concept of integration, the methodology and the construction of the integration measurement tools. In the last sections we analyze the data and outline the main challenges which hamper immigrants in Romania to secure stable employment and decent earnings and discuss their economic performances and opportunities on the Romanian labor market. 


\section{Last years have brought a steady increase of immigration figures}

Following the path of the other Central and Eastern European countries, Romania is experiencing an inflow of immigration as the economy creates more jobs than the available local work force could supply. Even though, judging by the size of its immigrant stock, Romania could hardly be considered a migrant destination, immigrant figures have constantly increased in the past years and migration streams have grown more complex and diversified. Compared to the first two decades after the fall of communism, when the number of foreign nationals living in Romania has been constantly low and stagnating somewhere between $0.5 \%$ to $1 \%$ of the national population (Migration Data Portal and UNDESA 2017), in the past four or five years these values have moved upwards. While Romanians continue to move permanently or temporarily to Western Europe for studies or for labor, the betterment of economic conditions and life standards of their country of origin have started to attract especially inwards large urban areas a various array of European mobile professionals, international students, entrepreneurs, non-European labor migrants and asylum-seekers who acquired refugee status in Romania (Coșciug et al 2017).

According to the Romanian authorities, the total number of immigrants living in Romania at the level of 2017 is 116,832 persons (IGI 2017). These figures include the beneficiaries of protection, those who have received political asylum in Romania (BP), migrants from outside the European area (RTT) and migrants from European member states (iEU) (IGI 2017). But this numbers do not include the category of foreign-born nationals who already obtained Romanian citizenship. The Immigration Inspectorate statistics deliberately leave this category aside focusing mostly on newly arrived immigrants. In this respect, the UN estimations are more comprehensive, as they include in their statistics the category of foreign-born nationals who acquired Romanian citizenship. This way the UN statistics exceed by far the numbers offered by the Romanian authorities, going all the way to more than 450,000 immigrants living in Romania at the level of 2018. These differences in operationalization and definition of immigrants and migration are not specific to Romania alone. Most states or intergovernmental or supranational entities operate with their own understandings and definitions of migration 
and have different priorities in immigrant integration (Bertossi 2008; Andreß and Careja 2018; Careja and Bevelander 2018). Nevertheless if we aggregate these values and follow the evolution of immigrant figures in the UN statistics, we can see that the magnitude of immigration in Romania is moving by the end of this year towards the share of $2.2 \%$ of the total population, overpassing other emerging destinations such as Poland but falling below Czech Republic and Hungary (Migration Data Portal and UNDESA 2018).

One of the fastest growing immigration flows is that of temporary economic migrants. In order to attract work force from abroad Romanian authorities increased the number of work permits issued every year for third country nationals who want to work in Romania (IGI, 2019) and local businesses and entrepreneurs turned to man power companies to recruit temporary labor for the manufacturing and construction sector, which have experienced a steady growth in the past decade. Romanian authorities issued more than 21,000 work permits in 2019 and the numbers are expected to grow in the upcoming years (Florea 2019).

In comparison, at the level of the European Union, during the same time frame, the share of foreign nationals living and working in various member states was the equivalent of $6.4 \%$ of the total population (Eurostat 2011). In the main destination countries from EU15 the share of immigrant stock was even higher, going up to figures which vary between 12 and 15\% (Migration Data Portal and UNDESA 2017). More than half of these figures represent third-country nationals who come from neighboring countries such as Turkey, Morocco, Syria and other countries in Northern Africa and the Middle East (OECD 2015, 300). But the pace of growth in established immigrant destinations has been infinitely lower, stagnating in the past years after decades of upward evolution. In Romania they almost doubled in the past ten years and are expected to grow in the following years as labor shortage is deepening. These numbers impose the rethinking of the current approach to immigration and the development of new immigrant integration policies. 


\section{Immigrant integration challenges}

Similar to the other migrant receiving destinations, the rapidly developing economies of Central and Eastern Europe are generating not only rewarding and high-wage stable jobs, which are desirable and entail increased social prestige (Portes et al. 1989). They also offer a wide-range of low-skilled, dangerous and less financially and professionally rewarding jobs in a similar fashion to more established immigrant destination such as the US or Western Europe (Dickens and Lang 1988). Political and economic forces within the liberal economic systems have the tendency of perpetuating segmented labor markets (Reich et al. 1973, 359), creating a form of economic dualism which creates a class of privileged workers located in the primary sector while expanding the class of precarious workers located in the secondary sector (Piore 1979). As the economic output of these countries has become more developed and complex, it has replicated to a certain extent the pattern of labor market segmentation existent in many developed western economies (Martin and Cristescu-Martin 2004). In the absence of powerful regulatory institutions coupled with neoliberal policies this has led to a higher wage inequality between educational groups than in many other developed European countries (Perugini and Pompei 2016). In addition Central and Eastern European countries struggle with a relatively high degree of informality and unregulated work which can leave immigrant workers with no social coverage and health insurance and expose them to abuse and mistreatment (Grzymała-Kazłowska 2015; Janská, Čermák and Wright 2014).

Immigrant workers are in general disadvantaged on the labor market of the host country, and are lagging-behind socio-economically, in comparison with the local native population (Phalet and Swyngedouw 2003). They tend to have salaries which are smaller than the wages of native workers with the same skills and employment position, with differences which can go between 6 to $8 \%$ of a monthly wage (Brücker et al. 2014). Evidence from migrant integration studies show that immigrants usually experience more frequently than the native population various forms of involuntary inactivity (OECD 2015: 81) and are more prone to be channeled in the informal economy (Bauder 2008; Stepick 1989; Piore 1979). Enabling immigrants to actively contribute to their receiving societies through increased labor market 
participation has become a concern of high priority for policy makers (Joppke $2007,245)$. Scholars and policy makers have come to the consensus that actively participating in the labor market will help immigrants become autonomous and productive members of the society and will increase their chances of being accepted by the native local population (OECD 2015, 9). Studies have also found evidence that a higher rate of active participation in the labor market amongst the first generation can pave the way for upwards social mobility for the second-generation (Granato 2014) and transform the economy of the destination state (Portes and Rumbaut 2006). In this respect, European welfare states started to dedicate considerable resources to facilitate immigrants' insertion on the labor market.

In order to facilitate integration, the EU institutions and main destination countries in Europe have mobilized significant resources in creating policies that deal with the challenges faced by newcomers in achieving positive economic outcomes in their host countries (Bratsberg et al 2017; Brochmann and Hagelund 2011). Some of these policies and strategies have particularly targeted third-country nationals, whose situation differs considerably from that of EU citizens engaged in various forms of intraEuropean mobility, as they experience restrictions on the freedom of movement, fewer social and political rights, and face greater risks of social exclusion and economic inactivity (OECD 2015: 300). For many years in a row their unemployment rate has remained higher than EU nationals and natives (Brochmann and Hagelund 2011; Lodovici 2010; Herzog-Punzenberger 2003). In order to counter these drawbacks, receiving states introduced various forms of social protection coupled with introduction allowances, language courses and training programs, measures which are expected to increase migrants' chances of successfully integrating in their new country (Brochmann and Hagelund 2011; Mau and Burkhardt 2009; Morissens and Sainsbury 2005).

However, such programs are often criticized for reproducing migrants' low socio-economic status and marginal social position. It is not entirely clear how effective integration policies are and what are the other factors shaping and modelling immigrants' integration trajectories (Ersanilli and Koopmans 2011). It is also not entirely clear which are the best approaches to immigrants' integration and which policies produce the best results (Brochmann and 
Hagelund 2011). In some cases, immigrants can acquire a large array of social and political rights without being economically integrated, while in other cases they can attain a good economic standing while being socially and politically marginalized (Portes and Rumbaut 2006; Borjas 1985). There is also evidence that acquiring the set of country-specific skills or the right kind of skills and improving the level of education does not lead automatically to better jobs and higher earnings (Duvander 2001). Immigrants are still exposed to various forms of discrimination. In Scandinavian welfare regimes such as Denmark, Sweden, and Norway, migrants fare much worse than the local population in terms of employment and income (Brochmann and Hagelund 2011). In Sweden, there is evidence that even immigrants who assimilate in the Swedish social life and acquire the country-specific social skills needed in a collaborative working culture have difficulties in finding a job (Duvander 2001). In Austria and Germany, the main immigrant group, the Turks, face a segmented integration on the labor market and usually have poorer educational results than the majority, characteristics which tend to reproduce themselves across generations (Herzog-Punzenberger 2003). In many migration destinations states, a large portion of immigrant households are below the poverty line (Morissens and Sainsbury 2005: 647). European statistics indicate that the relative poverty rate in EU countries is close to $17 \%$ but amongst immigrants this increases to $30 \%$, with $40 \%$ of immigrants' children living below the relative poverty line (double than the number of children of native households) (OECD 2018). Although host-state authorities and policy makers expect immigrants to attain in a short period of time a high level of convergence with the local population in terms of earnings, position on the labor market, cultural capital and system of values (Simonsen 2017, 3), integration does not happen overnight. Integration is a multidimensional process during which immigrants adapt themselves to the societal and institutional system of the host country, develop an understanding of the local norms of conduct of behavior, learn the language and acquire a specific form of local cultural capital (OECD 2015; Castles and Davidson 2000), being in fact a life-long process, which can sometimes take several generations (Andreß and Careja 2018, 5).

Several studies have tried to identify and analyze the factors which are responsible for immigrant's segmented integration on the labor market 
(Bernardi, Garrido and Miyar 2011; Kogan 2011; 2007; Dustmann and Fabbri 2005; Büchel and Frick 2005). Their findings indicate that the sociodemographic characteristics of immigrant cohorts (age, level of education and skills, legal status, origin country) as well as other measurable attributes such length of stay in the destination country or level of language proficiency are among the main variables which can explain their economic performances (Borjas 1985).

Other factors which are more difficult to measure such as the nontransferable qualifications and skills which immigrants attempt to capitalize on in the host country, employers' discriminatory practices, as well as their migration plans tailored on a temporary stay in the destination country also have a powerful impact in shaping their propensity to remain stuck in lowpaid, unskilled jobs (Anderson and Ruhs 2010; Piore 1979). Moreover, researches have shown that the level of labor market integration is significantly determined by institutional factors and policies such as labor market regulations and quotas for migrants, the welfare system, educational programs and integration policies of the receiving state (Kogan 2007; Reitz 1998). Despite the arguments which posit the convergence of European states towards a common integration model (Brochmann and Hagelund 2011; Joppke 2007), there are persistent and substantial differences in the way destination countries define the main migrant categories and their priorities in terms of immigration (Careja and Bevelander 2018; Ersanilli and Koopmans 2011). Across the European Union the level of immigrants' labor market integration varies significantly and some states are more successful than others in (Dustmann and Frattini 2012; Eurostat 2011).

In the case of Romania, immigrants are mainly concentrated in large cities and they are far from being pervasively present and visible in the everyday social reality and everyday life of the receiving society, as it is the case in many countries in western or southern Europe where immigrants constitute a visible and recognized social group. However, especially in the large and economically dynamic urban centers in Romania (many of them located in the Immigration Region no. 1 which comprises Bucharest and surrounding counties), foreign workers are starting to become part of the local economy. The following sections outline the current dynamics of immigrant 
integration and map out the main factors and tendencies driving and hampering their labor market integration in Romania.

\section{Methodology}

Based on the official data received from the Immigration General Inspectorate, we carried out a stratified sampling to weigh the data obtained from the questionnaires. In the first stage of data collection we translated the questionnaire from Romanian into 5 other international languages spoken by the main immigrant groups - Turkish, Arabic, French, English and Italian. A total of 718 questionnaires were collected, out of which 193 questionnaires were completed online and 525 were filled in directly by respondents with the help of questionnaire operators. Of the 718 questionnaires, some were excluded because the data provided by the respondents were insufficient ( 38 cases), because the respondents had Romanian citizenship or citizenship of another state and the Romanian one (83 cases), or because the respondents were citizens of EU or EEA member states or had the nationality of an EU or EEA member state (60 cases for the 2017 data set). The remaining 537 responses were weighted according to the main socio-economic characteristics of immigrants in Romania that we obtained from the Immigration General Inspectorate data (2017). Thus, the maximum permissible error is 3\% for a $95 \%$ confidence threshold. The survey has been conducted across all five regions of migration in Romania and managed to cover the entire spectrum of foreign legal residents.

Another set of information has been collected from local, regional and national institutions working with immigrants. We designed a set of questions adapted for each institution and sent them the questions online. The data has been stored into an online platform collecting data from all the institutions surveyed in this project.

Furthermore, in the second stage of data collection, conducted throughout 2018, we applied a new set of questionnaires in which we merged some of the immigrant integration dimensions and indicators and added a new immigrant category - the EU nationals living in Romania, a category that was deliberately left outside in the first round of questionnaires and the foreign-born nationals who acquired Romanian citizenship. We collected 645 
questionnaires, filled online or directly by respondents in the presence of field operators. We have equally addressed a set of online questions to the Romanian institutions involved at various levels of governance in immigrant integration process which we stored and indexed on an online platform. More details about the data collection process and the measure that were employed in order to meet the criteria of representativeness can be found in the Romanian Immigrant Integration Index (Cosciug et al. 2017).

In order to measure labor market integration we used several dimensions such as employment and unemployment rate, share of active immigrant population, income level, self-employment rate, underemployment, contractual forms, and rate of retaining skilled labor which we have previously employed in the 2017 edition of the Romanian Immigrant Integration Index (Cosciug et al. 2017).

\section{Patterns of integration}

Moving further with our discussion, before we start the analysis of labor market integration tendencies, we have to look at the structure of the legally resident foreign nationals in Romania. The share of legal foreign residents who came to Romania to work is much lower compared to those who came for family reunification or for studies (IGI 2016; IGI 2017). Equally important, the share of low skilled and medium skilled immigrants is lower than in other countries with high labor migration levels. Immigrants living in Romania have in general a higher level of education than the average of Romanian society and live in urban areas (Romanian Immigrant Integration Index 2017). They also tend to be much younger than the rest of Romanian population, with the proportion of the young population among foreign nationals in Romania being larger than the proportion of young people in the local national population (OECD 2015, 39). They are a relatively recent immigrant group in Romania and not all of them plan to make their stay permanent. But they seem to have similar levels of income in comparison to the local population and to work similar working hours. Moving onwards, we will try to grasp their professional and economic trajectories and map out their position on the Romanian labor market. We are looking for the modes of incorporation of immigrants into the Romanian labor market and we aim to 
analyze and grasp the variety of factors that impact integration and inequality attainment (Wilson and Portes 1980).

5.1. Indicator 1: Employment and unemployment rate and share of active immigrant population

The analysis conducted alongside the employment and unemployment indicator revealed that, despite the recent increase of labor migration, the data collected for the 2017 edition of the Romanian Immigrant Integration Index shows that only a third of the non-EU immigrants living in Romania currently have or have had a job throughout their stay, compared with the EU average of $67.4 \%$ (OECD 2018). Another important finding is that most of the third country nationals have come to Romania for studies (59.8\%). The highest level of labor integration has been attained by those persons who are members of households composed by Romanians or European citizens, although at this moment, the relatively recent date of immigrant groups on Romanian territory does not allow us to establish a causal link between status, the country of origin and their level of integration. Most immigrants are working in the private sector and have similar earnings to the rest of Romanians.

Figure 1.1 Immigrants' employment rate according to the legal status in Romania (2017)

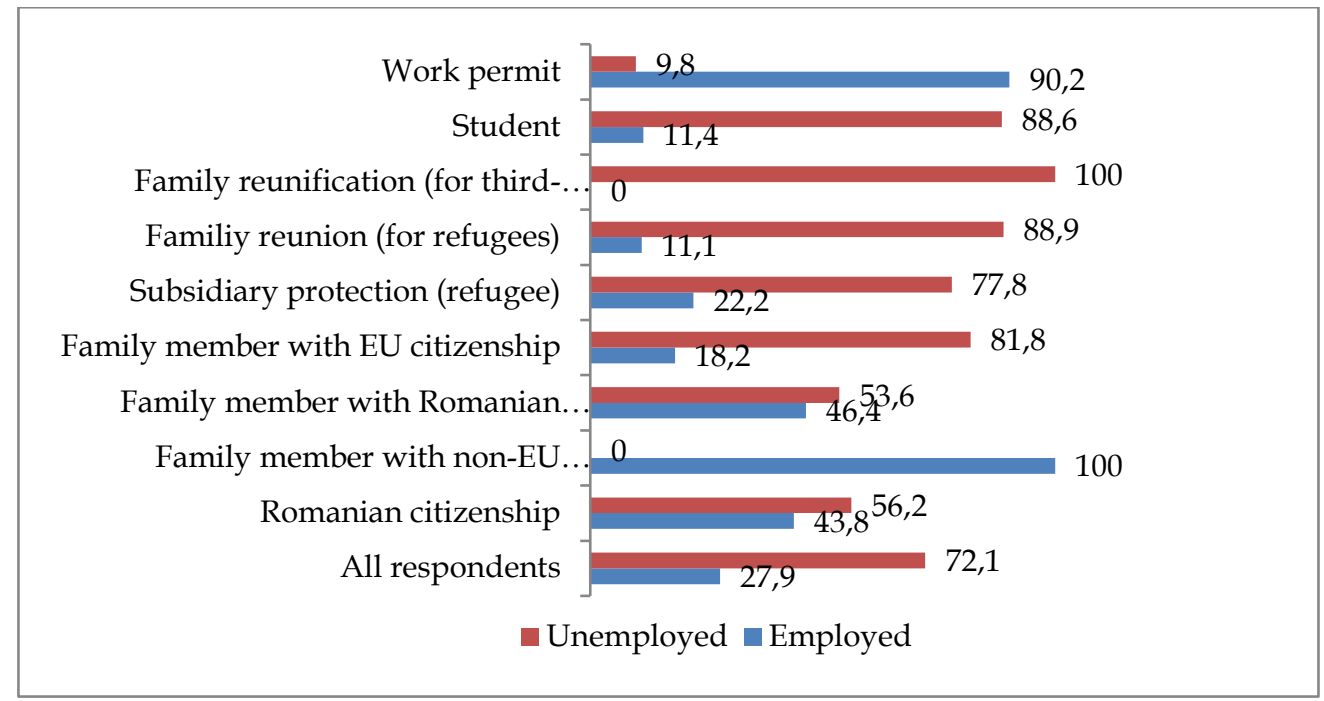

Source: Romanian Center for Comparative Migration Survey (2017) 
Moving on and looking at Figure 1.2 with the data set from 2018 we see that family reunification, labor and studies remain the main reasons of entry. However, we can notice in this data set the slight increase of the labor migration inflows which have overpassed the stock of those arriving for studies. This confirms the constant increase of labor migration from the past years.

Figure 1.2 Main reason of entry in Romania according to immigrants' legal status (2018)

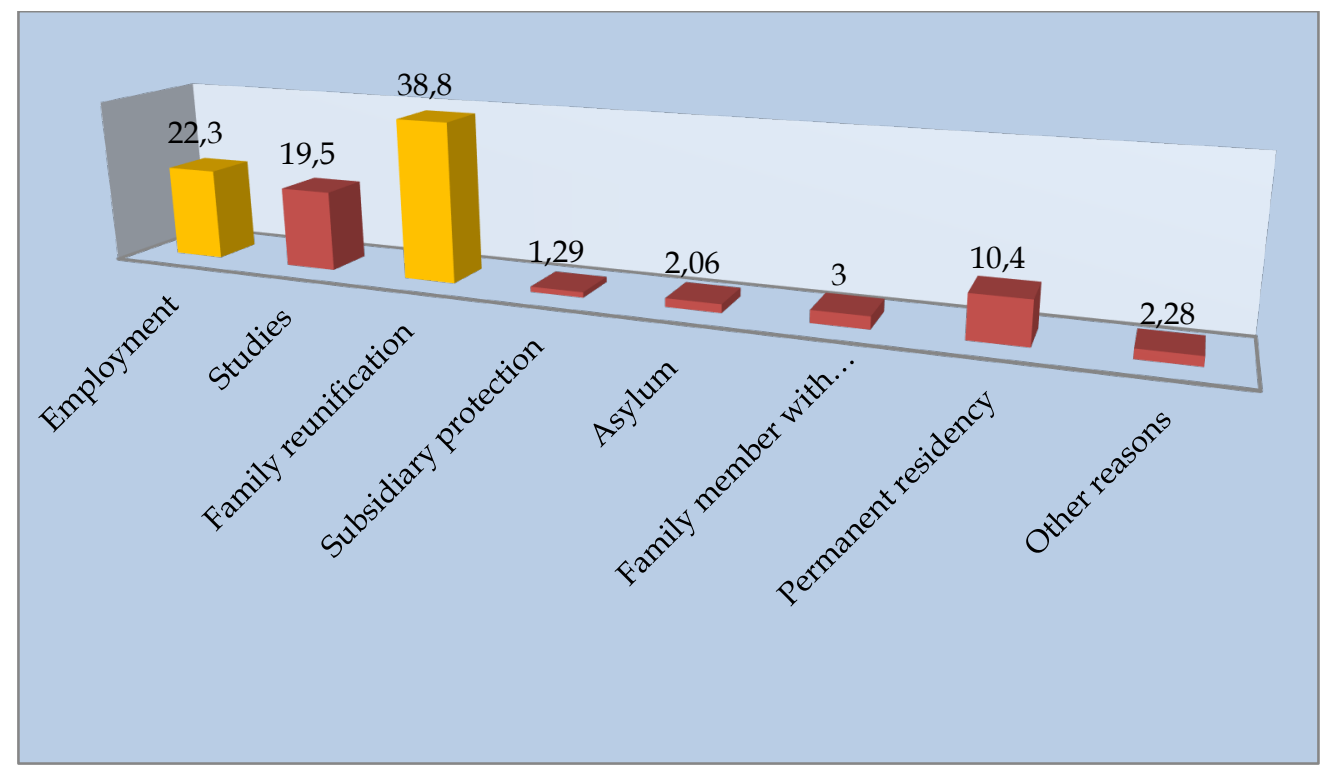

Source: Romanian General Inspectorate for Immigration (2018)

In terms of regions and countries of origin, our survey indicates a high heterogeneity of the immigrant structure in Romania. Unfortunately, the lack of longitudinal data constrains us in drawing correlations between the region of origin and the level of integration and socio-economic status.

Incorporation into the labor market is a good indicator of the formal and structural integration of immigrants in the host country. In general, first and second-generation immigrant groups tend to have lower levels of integration compared to host country nationals, despite positive policies and labor 
market integration measures (OECD 2015, 13; Koopmans 2010). In Romania however, it is early to generate any conclusions on this issue as migration is rather recent and immigrants have a limited labor experience in Romania. In Figure 1.3 we see that Southeast Asian and Latin American have the highest share of persons with labor experience in Romania. This confirms the recent increase of immigrant labor flows from South-East Asian arriving as temporary migrants to work in the construction sector or child-care through labor recruitment schemes. But it makes it almost impossible to link a successful level of integration to belonging to a specific country of origin, as we see in studies conducted in countries with a long history of immigration (Portes and Rumbaut 2006).

Figure 1.3 Third-country nationals' and refugees employment status by region of origin

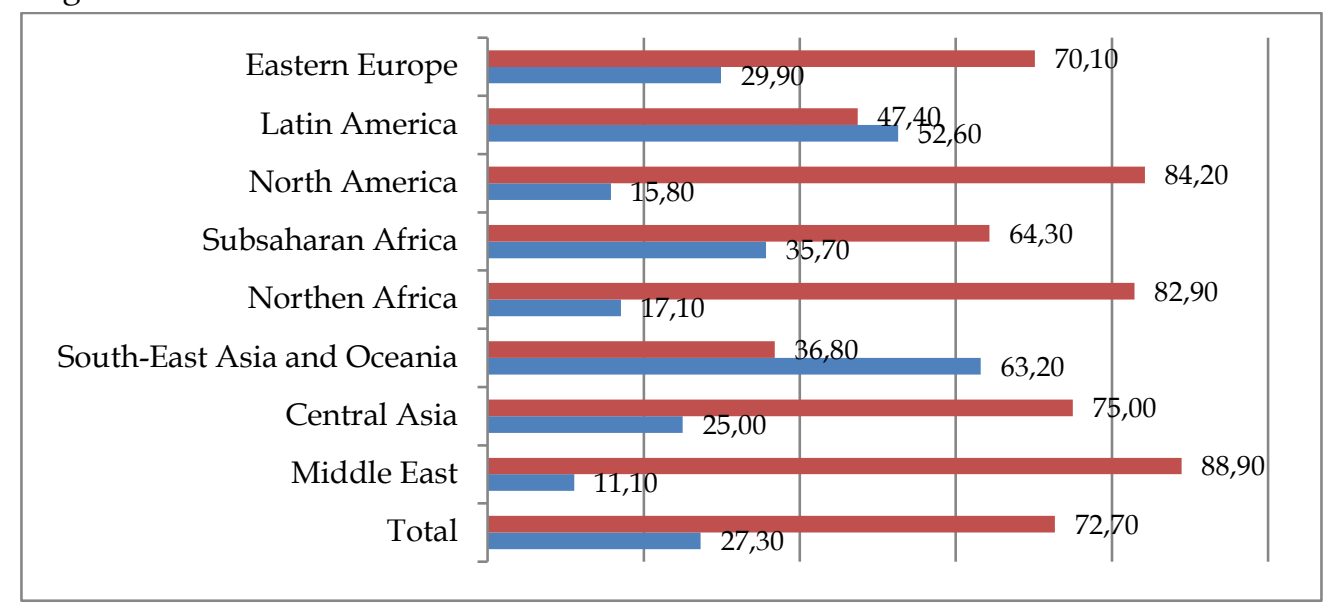

Source: Romanian Center for Comparative Migration Survey (2017)

\subsection{Indicator 2: Income}

The next indicator of labor market integration is income. Data on monthly income is extracted from questionnaires addressed to third-country nationals and refugees during the 2017 survey, and to third-country nationals, refugees, European citizens and foreign nationals with Romanian citizenship for the 2018 data collection. Within the EU labor market, third-country nationals earn on average less than European citizens and are more likely to live in poverty than European citizens. Regarding the situation in Romania, the income 
distribution among immigrant categories of refugees and third-country nationals shows a slightly different situation than the rest of European countries. Their average earnings are at similar levels to the local population, the difference in average monthly income being lower than in the rest of the European countries, this being translated into immigrant earning the average salary in Romania.

According to the Labor Code and the Law no. 53/2003 (Labor Code) (GEO no. 194/ 2002 regarding the regime of foreigners) immigrants who have the right to stay in Romania for work purposes have a different minimum wage regime than the national minimum gross wage. The minimum wage established by the full-time individual employment contract must be at the level of the average gross salary. Highly skilled workers (holders of the Blue Book) are entitled to a minimum salary equivalent to four times the national average gross wage.

Exception from the minimum wage limit provided in GEO 194/2002 with subsequent amendments and completions it only applies to migrant workers employed in the budgetary system and paid from public funds (IGI 2018).

Considering this backdrop, the immigrants' average monthly income was 2059 lei, and the median monthly income was 1300 lei for 2017. During the same time frame the monthly average net income of Romanian nationals was 2629 lei (INS 2018), while the median monthly income was just slightly over 1500 lei (Eurostat 2016), at one of the lowest levels in Europe. However, the income convergence of immigrants and the local population is higher than for other European countries, where the wage difference between the national population and the non-EU population may exceed $20 \%$, as in the case of Germany, Austria or France (Eurostat in 2015). In other words, in Romania the discrepancy between the earnings of immigrants are not so different from those of the local population.

For 2018 the situation changes considerably with immigrants reporting higher earnings. The net monthly average income declared by the respondents is above the national average, with immigrants earning more than 4150 lei compared to the value of 2714 lei, which was the average 
monthly net income in Romania in 20181. However, when we look at the distribution of income, we see that over $43.7 \%$ of the respondents register incomes below 2000 net lei per month, while only $19.1 \%$ earn the sum of the average monthly salary. Regarding income distribution, to a certain extent, immigrants living in Romania tend to be as polarized in terms of monthly incomes as the rest of the population. A significant percentage of people have earnings above the national average, while a relative majority of $43.7 \%$ register income below the monthly average salary. In some domains, such as construction working salaries tend be higher than the national average. But, as we will see in the graph below, not all immigrants work in the construction sector. Most of them are employed in the hospitality industry and service sector, where salaries are usually lower.

Figure 2.1 Monthly income levels among immigrants living in Romania (2018)

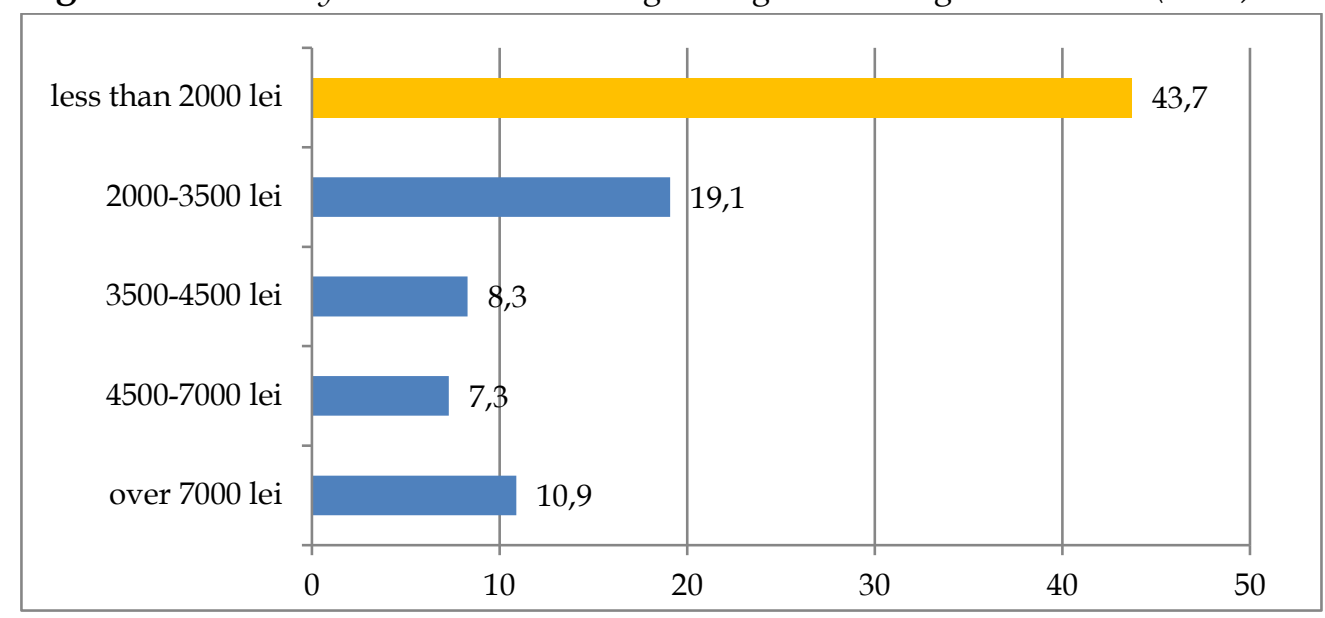

Source: Romanian Center for Comparative Migration Survey (2018)

\footnotetext{
${ }^{1}$ National Institute of Statistics, http://www.insse.ro/cms/ro/content/c\%C3\%A2\%C8\%99tigurisalariale-din-1991-serie-lunar\%C4\%83, accessed 25.07.2018
} 
Figure 2.2 Monthly income categories amongst immigrants in Romania (2018)

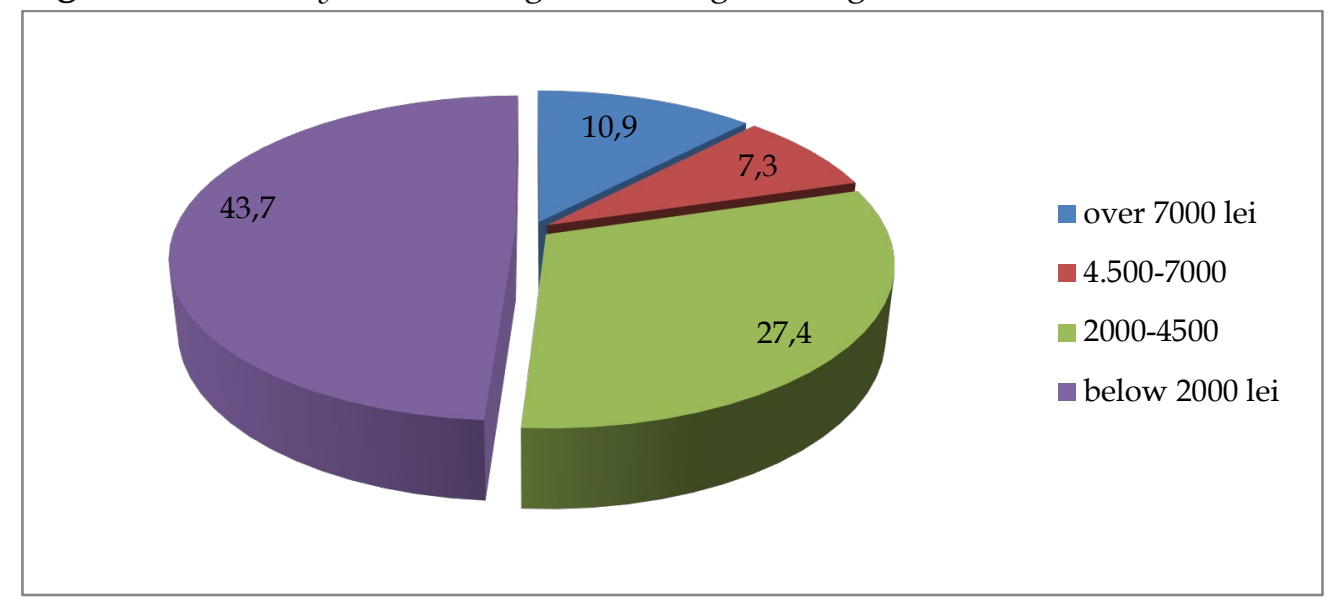

Source: Romanian Center for Comparative Migration Survey (2018)

These income figures should be equally analysed in relation to the socioeconomic context of immigrants living in Romania. Therefore, we must not forget that compared to the local population, immigrants are in a much more vulnerable situation due to the large proportion of fixed-term work contracts, the lack of family and kin support networks and lack of complementary sources of income or additional resources. Equally, immigrants are largely concentrated in urban areas where they are living in rented apartments or houses (Burean 2017). Given the fact that migratory flows targeting Romania are relatively recent, most immigrants do not own a house of their own, thus spending a large share of their income on housing. This translates to a much more reduced disposable income and a larger share of their earnings spent on housing and necessities.

\subsection{Indicator 3: Self-employment level among third-country nationals}

In order to map-out the number of foreign nationals who are self-employed, during the 2017 data collection we requested the Direction for Asylum and Integration within the General Inspectorate for Immigration (GII) some information about the situation of self-employed immigrants living in Romania. We collected these data through an online questionnaire attached to an online platform specially dedicated to public institutions (see IIIR, Cosciug et al. 2017). We solicited information on the number of foreign 
nationals residing legally in Romania, differentiated according to the legal status, age, region of residence, country of origin, who were self-employed in 2016. The very low response rate $(10 \%)$ prevents us from presenting conclusive and valid data for this indicator and drawing conclusions about the rate of self-employed. The only office that reported exact figures about self-employed workers is the Bucharest office. The other agencies from the rest of Romanian provinces responded that they did not have such data or that there were no active persons registered as self-employed. According to OECD (2019) in EU the highest self-employment rate among foreign-born nationals is in Italy $(23.2 \%)$ and Greece $(34.1 \%)$ and the lowest in Denmark $(8.2 \%)$.

On a second attempt, we directly surveyed the four categories of immigrants covered by the 2018 data collection, trying the measure the share of those that are self-employed. Surprisingly, if we look to the Figure 3.1 the data shows that over $48 \%$ are self-employed. But the result should be taken with caution. From the 645 respondents roughly only a third is working or worked in Romania at the time when they survey was conducted.

Figure 3.1 Share of self-employed immigrants living in Romania

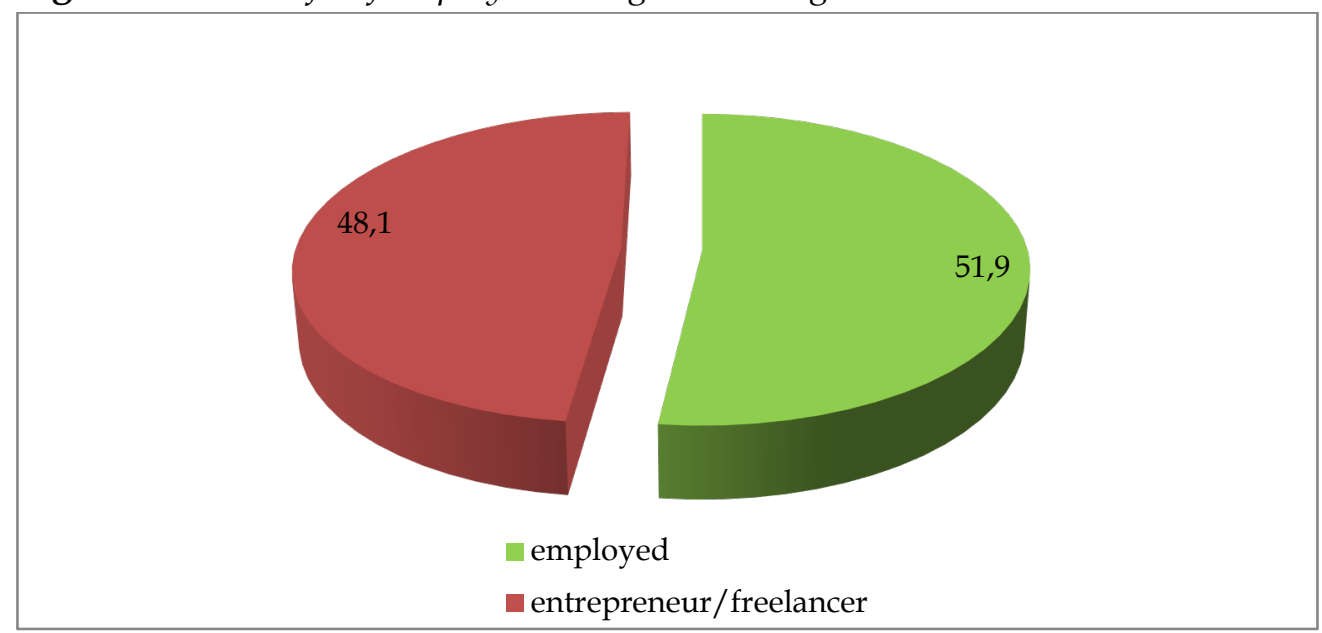

Source: Romanian Center for Comparative Migration Studies Survey (2018) 


\subsection{Indicator 4: Rate of overqualified workers and underemployment}

We move on now to the dimension of underemployment. We see in the chart Figure 4.1 displayed below how respondents who have indicated vocational education as the last graduate school have better employment opportunities than those who have just graduated primary school or gymnasium. This category enjoys better prospects, even when compared to university graduates. Thus, $83.3 \%$ of the persons in this category indicated that they are currently employed or have been employed in Romania. The next category in the order of access to the labor market is represented by the group of respondents who indicated university as the last school they graduated, a group in which almost $40 \%$ indicated that they were employed or previously had a form of employment. Related to this indicator, Romania resembles to other contexts where migrants generally occupy jobs below their qualification level or face difficulties in transferring their skills and fully equalizing their professional qualifications in the destination country (Massey et al. 1990; Piore 1979). Immigrants are usually less likely than the host country population to get a job in positions requiring university studies or matching their levels of qualifications (Duvander 2001).

If we are looking at the EU countries, they will see that the share of highly educated immigrants increased by $7 \%$ in the last ten years, while the share of highly educated individuals amongst the native population grew even more (10\%) (OECD 2018). According to the OECD report (2018), in the EU countries over $25 \%$ of low-skilled jobs are occupied by immigrants, with countries like Luxemburg and Switzerland where this quota is over $60 \%$. When we look at inactive migrants, we can see that about $25 \%$ of them wish to work compared with $16 \%$ of the national population.

In the case of the refugees and third-country nationals living in Romania, the current distribution is strongly influenced by study-oriented immigration, with most of the respondents of the 2017 survey being here for a fixed period of time until the completion of their studies. However, more than $60 \%$ of those who work or worked in Romania said that the occupied job corresponded or corresponds to their current training and professional qualification. 
At the EU level, highly educated immigrants are $50 \%$ more likely than the native population to either occupy positions for which they are overqualified or to be unemployed (OECD 2018). Moreover, amongst the immigrant workers, refugees are at a higher risk to be overqualified.

Figure 4.1 Immigrants' employment status depending on their level of educational attainment

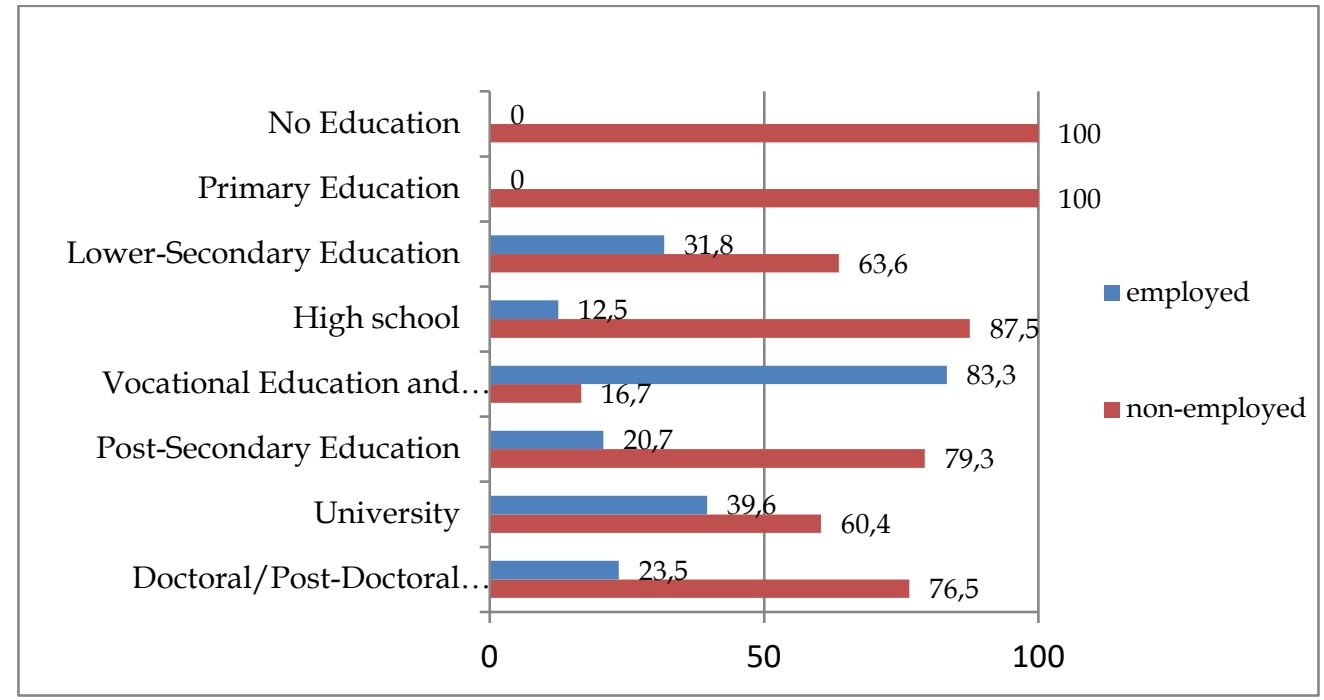

Source: Romanian Center for Comparative Migration Studies Survey (2017)

Figure 4.2 Share of respondents who consider that their current occupation corresponds to the level of qualification (2017)

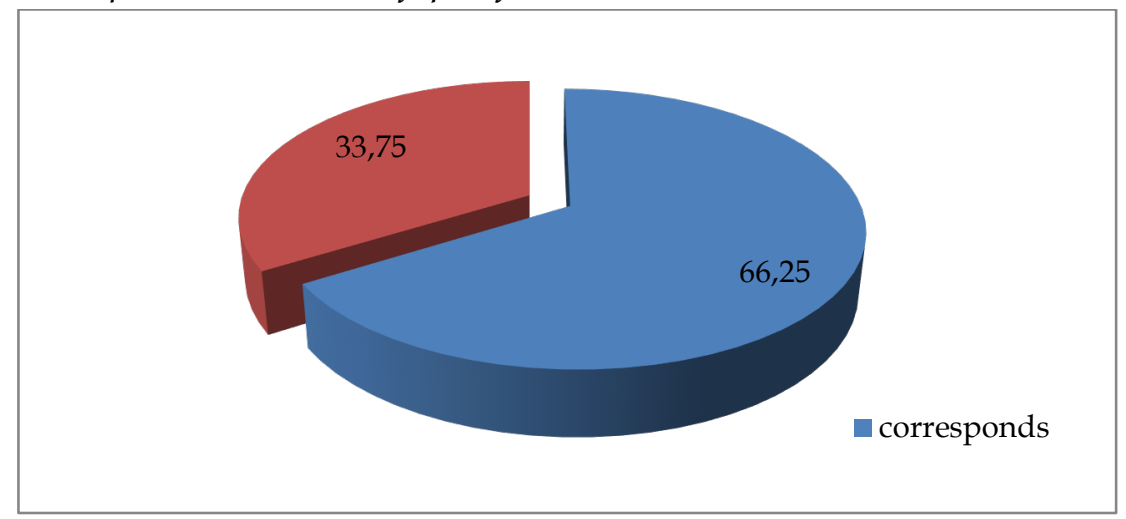

Source: Romanian Center for Comparative Migration Studies Survey (2017) 
Figure 4.3 Share of respondents who consider that their current occupation corresponds to the level of qualification (2018)

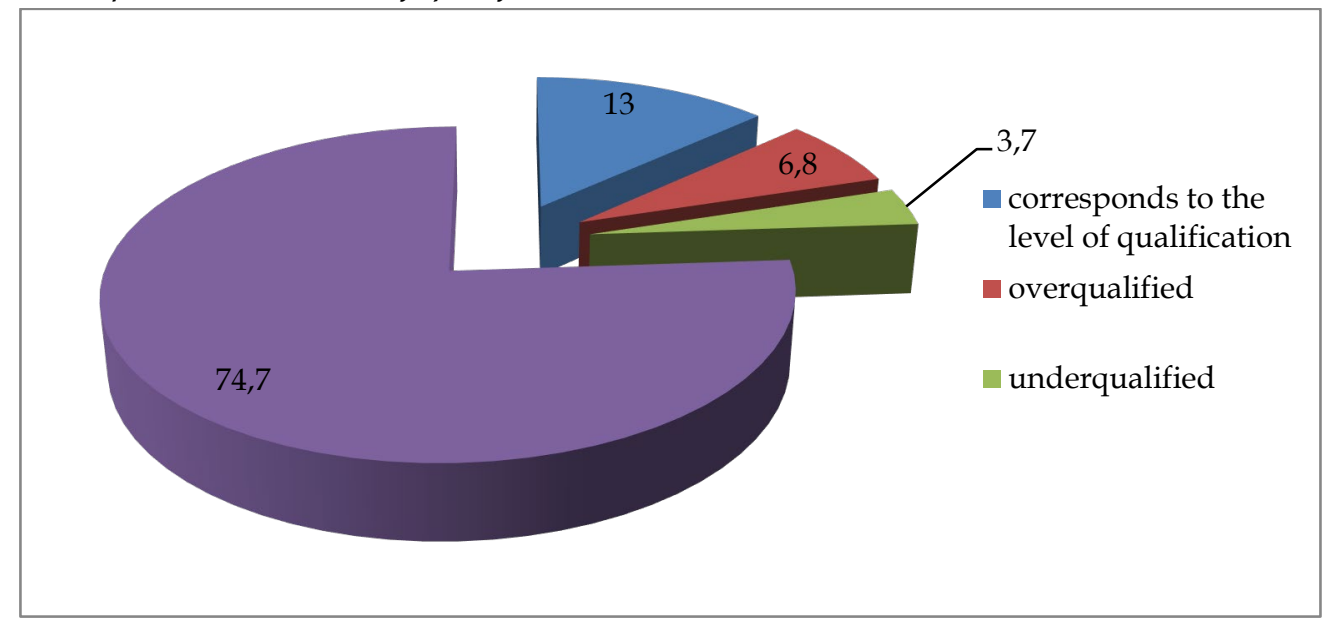

Source: Source: Romanian Center for Comparative Migration Studies Survey (2018)

If we look at the data collected in 2018, we see a similar picture. The share of those that consider themselves to be overqualified is relatively low. This result can be explained by the fact that the majority of immigrants working in Romania have been recruited on temporary labor contracts. Their main purpose is to work for a period, remit money home and probably return after they consider that they accumulated enough money. In this case they do not perceive working in lower and medium skilled jobs as something that does not match their qualification level.

\subsection{Indicator 5: Contractual forms, long-term and fixed-term employment}

Since it appears that the rate of underemployment is relatively modest, we move on to the next indicator, through which we want to map out the type of employment contracts immigrants work in Romania. For capturing this we used two types of tools: an online questionnaire addressed to the Territorial Labor Inspectorate and a questionnaire addressed to third-country nationals and refugees for the 2017 survey. Through the questionnaire addressed to the Labor Inspectorate in each county, we requested data on the number of fulltime and part-time contracts of foreign-born workers. The county offices had a high rate of response, but only $13 \%$ reported data on the requested information, $87 \%$ mentioning that they do not have such data or that they do 
not have a special methodology to register and differentiate the third-country nationals and refugees who are legal residents and work in Romania. Subsequently we sent out a questionnaire addressed to third-country nationals and refugees. As represented in the graph below, we see that most of the foreign nationals who are employed or have been employed in Romania work on fixed-term contracts. Only 39.2\% benefit from permanent contracts.

Their situation is again much more precarious than that of the local population. Romania has one of the lowest European values of fixed-term contracts, with a rate below $10 \%$ from the total number of registered work contracts. The rate of immigrants working on this type of contracts is six times larger. Although they have a monthly income similar to the rest of Romanians, close to the national average and median value, the higher rate of fixed-term employment contracts not only that makes their situation more precarious but also raises questions about their long-term plans of staying in Romania. For 2018 we sent out a new set of questionnaires, including European citizens and foreign nationals that acquired Romanian citizenship.

We can see from the results in Figure 5.2 and notice that the situation remains pretty much stable in comparison to the first survey.

Figure. 5.1 Type of employment contract (2017)

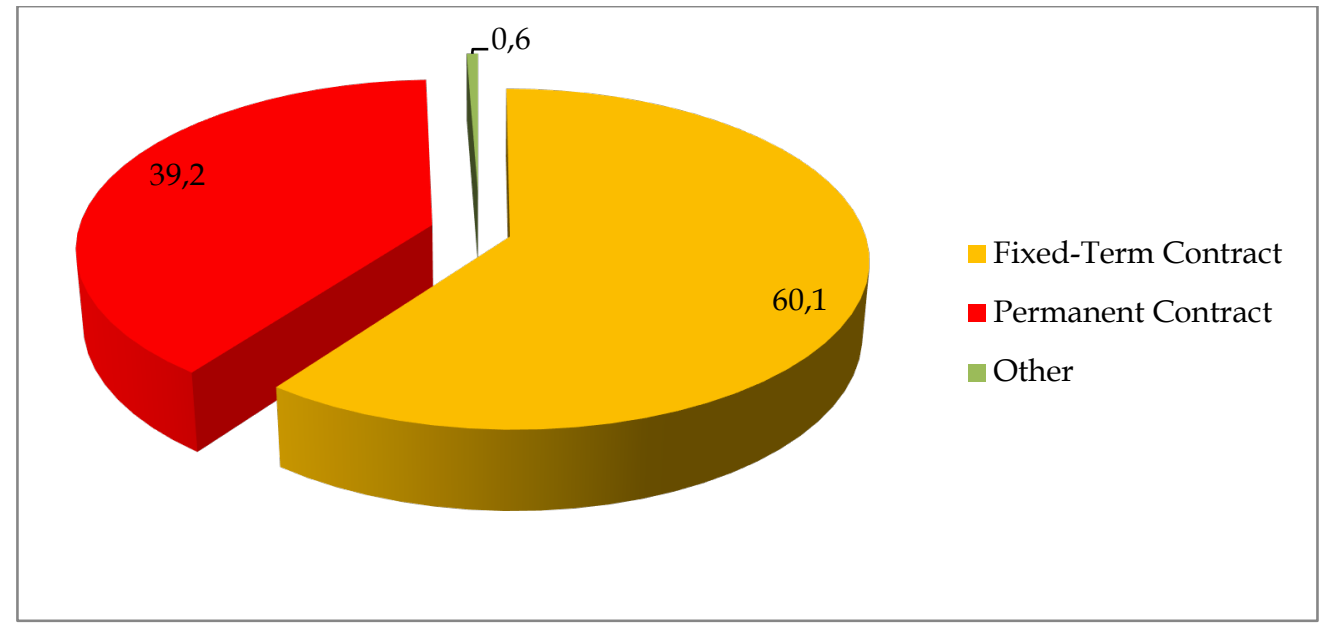

Source: Romanian Center for Comparative Migration Studies Survey (2017) 
Figure 5.2 Type of employment contract (2018)

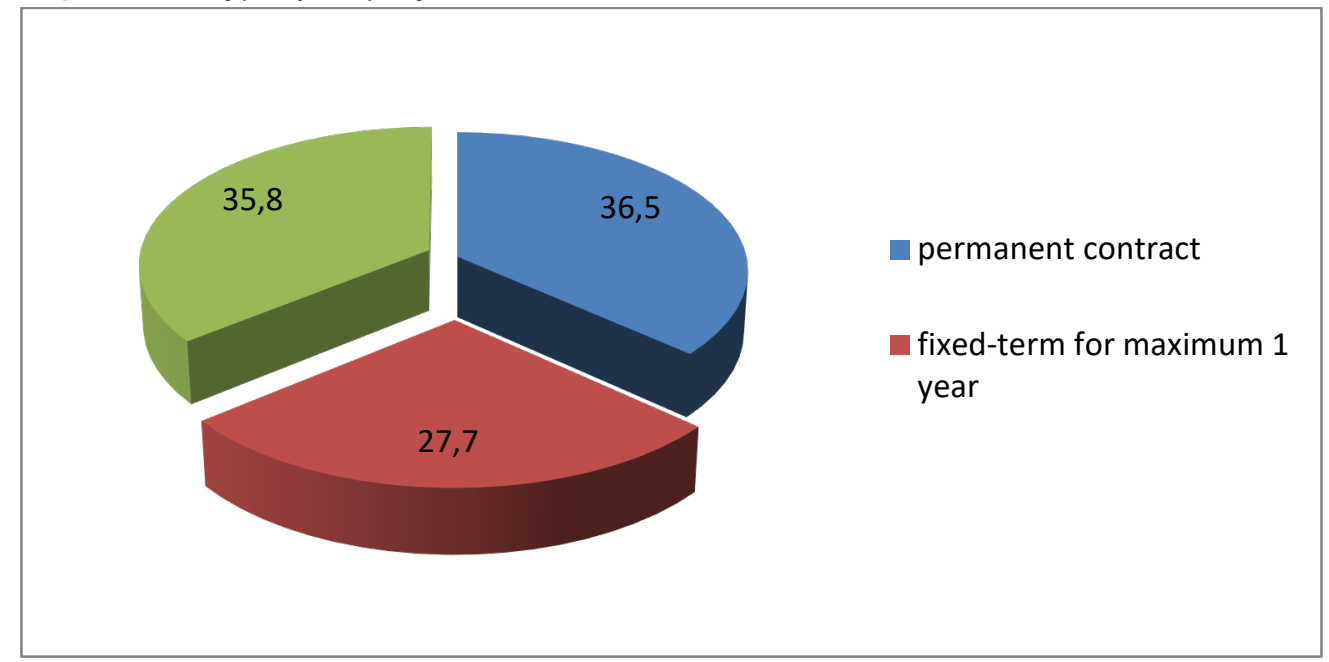

Source: Romanian Center for Comparative Migration Studies Survey (2018)

Almost $60 \%$ of those who work or had been employed in Romania from the 2018 survey are still employed on fixed term-contracts. Again, one of the plausible explanations for this result is that some of these respondents have been employed through recruitment schemes that bring immigrants to Romania on fixed-term contracts which are periodically renewed.

Regarding working hours, we can see in the graph below that those who have permanent contracts work on average 8.4 hours a day, while those with fixed-term contracts work on average 7.3 hours a day. Based on the analysed data, immigrants in Romania tend to have a work program similar to the local population, reporting an average of 7.78 hours worked per day. 
Figure 5.3 Number of working hours on a regular work day reported immigrants in Romania (2017)

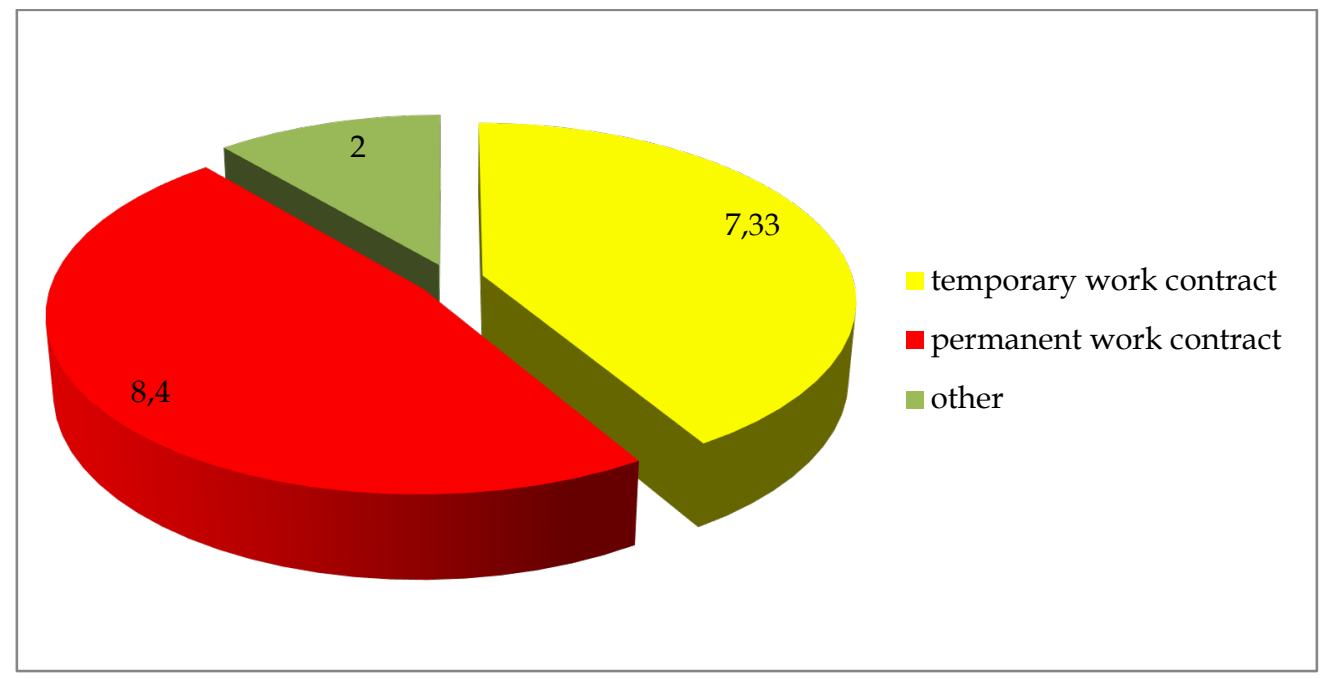

Source: Romanian Center for Comparative Migration Studies Survey (2017)

In 2018 we addressed a question that was not addressed in the previous survey. We ask the participants if they work at least 12 hours a week, leaving the definition of work as open as possible. We see from this question that the number of those who answered "not working at all' or "working less than 12 hours a week' remains constant, with only a third of respondents working at least 12 hours a week. 
Figure 5.4 Share of respondents who work more than 12 hours a week (2018)

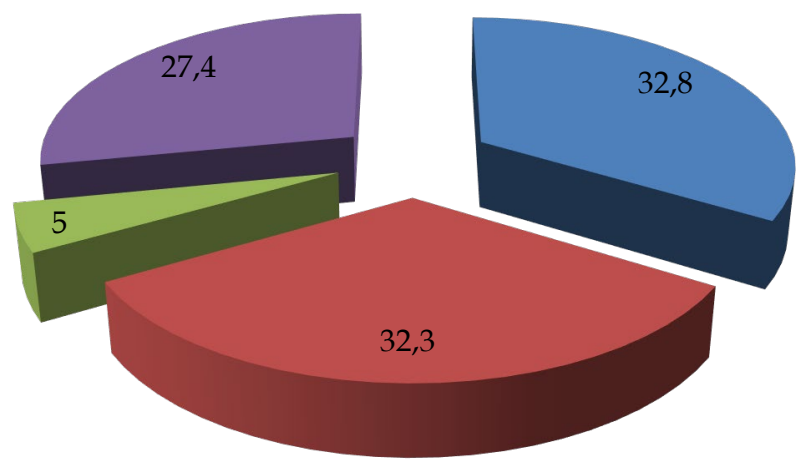

- yes

no

- other answers

a do not work

Source: Romanian Center for Comparative Migration Studies Survey (2018)

Figure 5.5 Reasons why respondents do not currently work at least 12 hours a week (2018)

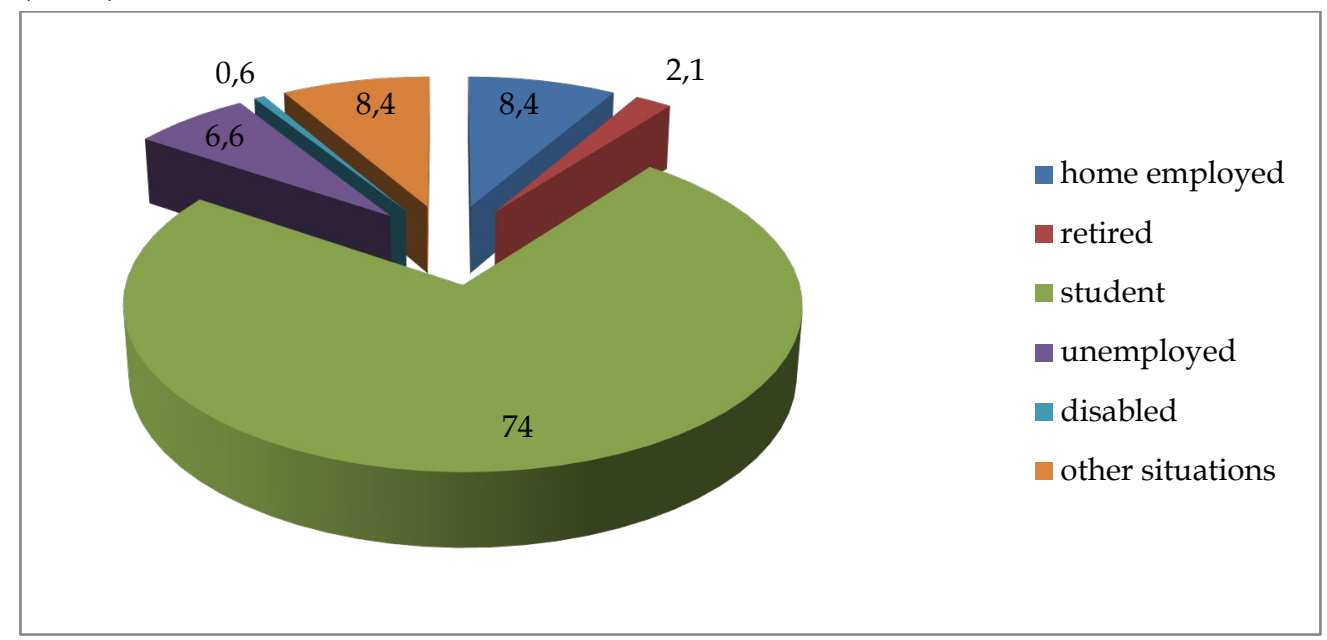

Source: Romanian Center for Comparative Migration Studies Survey (2018)

Subsequently we addressed a new question aiming to verify the reasons that impede immigrants to work more than 12 hours a week. From this question we can see that very few are unemployed, or home employed. In this case, Romania has lower immigrant unemployment numbers than the rest of 
western European migrant receiving countries. As we have seen before in other graphs, the majority of respondents do not work or work less than 12 hours a week due to their enrolment in university studies (or other type of studies). Although this might seem less positive from the perspective of filling the increasing shortage of skilled professionals needed on the Romanian labor market, if we think on the long term and manage to implement the appropriate measures of retaining a share of this group upon graduation, the current intake of migrants coming for studies might become an important advantage and asset for the Romanian economy.

\subsection{Indicator 6: Retaining skilled labor}

In order to track down the retaining rate of skilled labor we started by addressing a set of online questions to the Labor Inspectorate. The response rate recorded on the online platform was very low, which is why no statistical analysis can be currently made based on this data. Therefore, we have built our analysis on the data collected through questionnaires administered to immigrants throughout the 2017 survey.

When it comes to future prospects, we saw that the current occupational status determines to a large extent immigrant's intention of remaining in Romania. On one hand, those who are currently working are also those who intent to stay in Romania in the long run. On the other hand, students' migration trajectory and plans are strongly influenced by the duration and field of undergraduate or graduate studies, most of them intending to leave Romania after completing their studies (Coșciug et al. 2017).

In the graph below we can see that the intention to stay is strongly influenced by the immigrants' current occupational status. More than $30.8 \%$ of those who are not currently working (grouped in the 'No' section) reject the option of remaining in Romania. Together with those who responded 'unlikely', these two quintiles are approaching 50\% of the total respondents. Looking at the distribution of responses to the intention to stay in the category that has a job, we see that the current occupational status determines to a large extent the intention of prolonging their stay for the future. Those who are currently working outline themselves as a distinct category whose intent is to stay in Romania long term. 
Figure 6.1 Third-country nationals and refugees' intentions to stay based on their current occupational status (2017)

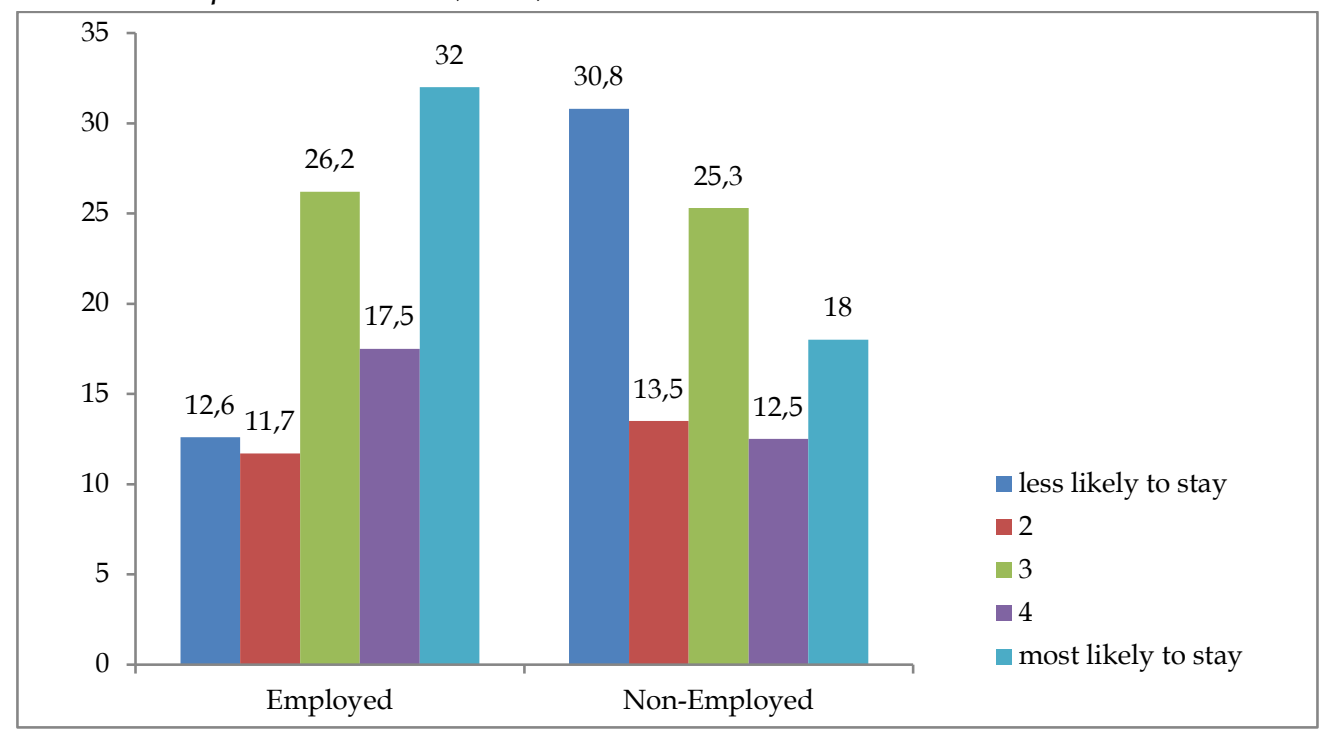

Source: Romanian Center for Comparative Migration Studies Survey (2017)

\subsection{Indicator 7: Public sector employment}

To measure the employment rate in the public sector, we used the data extracted from the questionnaire applied to the population with the right of legal residence in Romania at the level of 2017.

Of this category, $63.5 \%$ work in the private sector, $10.6 \%$ in the nongovernmental sector and $25.9 \%$ in the public sector. If we compare these percentages with the distribution of jobs within the national population, the share of those working in the state institutions from the category of foreign nationals is similar to the share of public sector employees among Romanian citizens. 
Figure 7.1 Rate of immigrants employed in the public sector in Romania (2017)

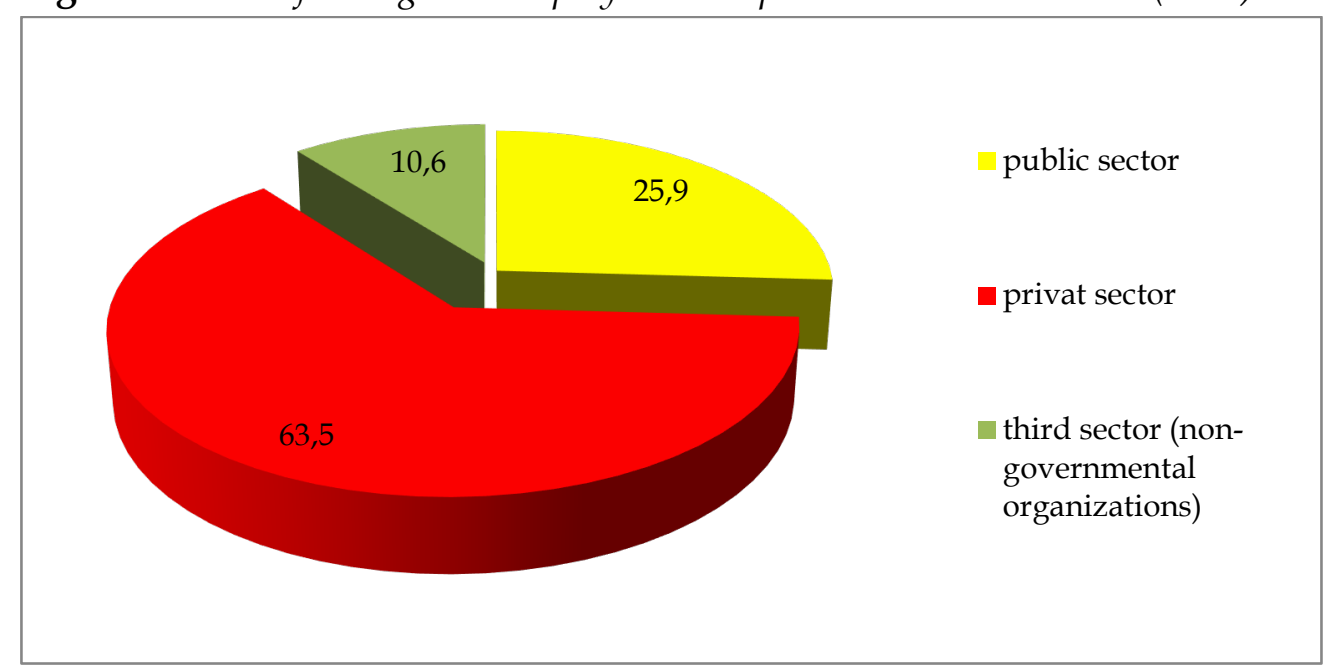

Source: Source: Romanian Center for Comparative Migration Studies Survey (2017)

Figure 7.2 Immigrant main domains of employment in Romania (2018)

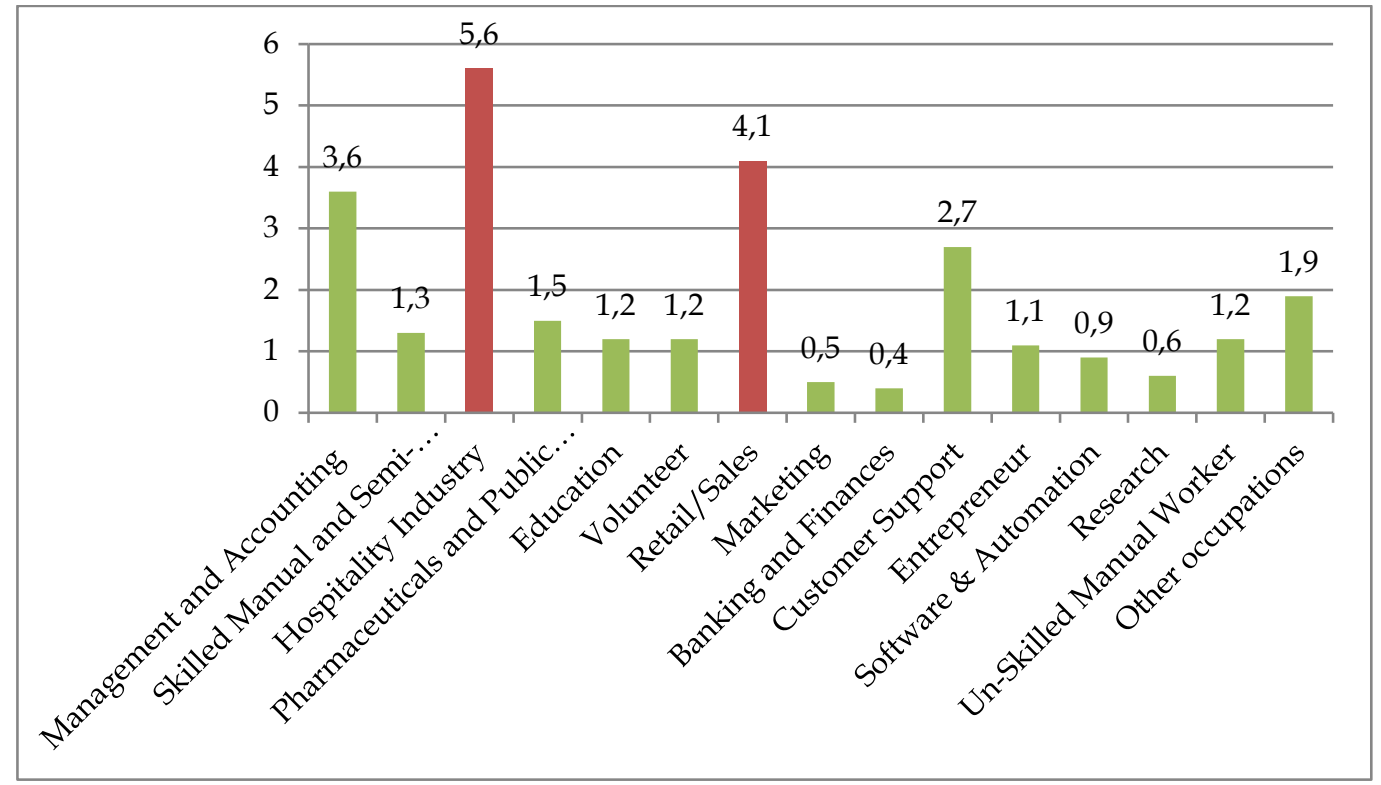

Source: Romanian Center for Comparative Migration Studies Survey (2018)

When we look at the proportion of employees in the public sector (which comprise public administration, education, health and social work) within EU, we see that in 2011 one quarter of the employed native-born 
population was working in the public sector, whereas when it comes to the foreign-born residents only 18,9\% occupied a similar position in the public system (Eurostat, 2011). Romania seems to have a slightly higher share of immigrants who work in the public system than the European average.

In 2018 we asked a set of different questions, allowing respondents to situate themselves according to their own perception and understanding in a certain professional field or economic sector. From the graph 7.2 above we can see that the majority works in the tertiary sector, in domains such as the hospitality industry, sales, accounting and management and customer support. When we reorganized the graph for a better view of their domains of activity, we see that again the vast majority is not working (most likely this category overlaps to a large extent with the group who are enrolled in university programs), and about $20 \%$ are working in the secondary and tertiary sector.

Figure 7.3 Respondents domains of employment in Romania (2018)

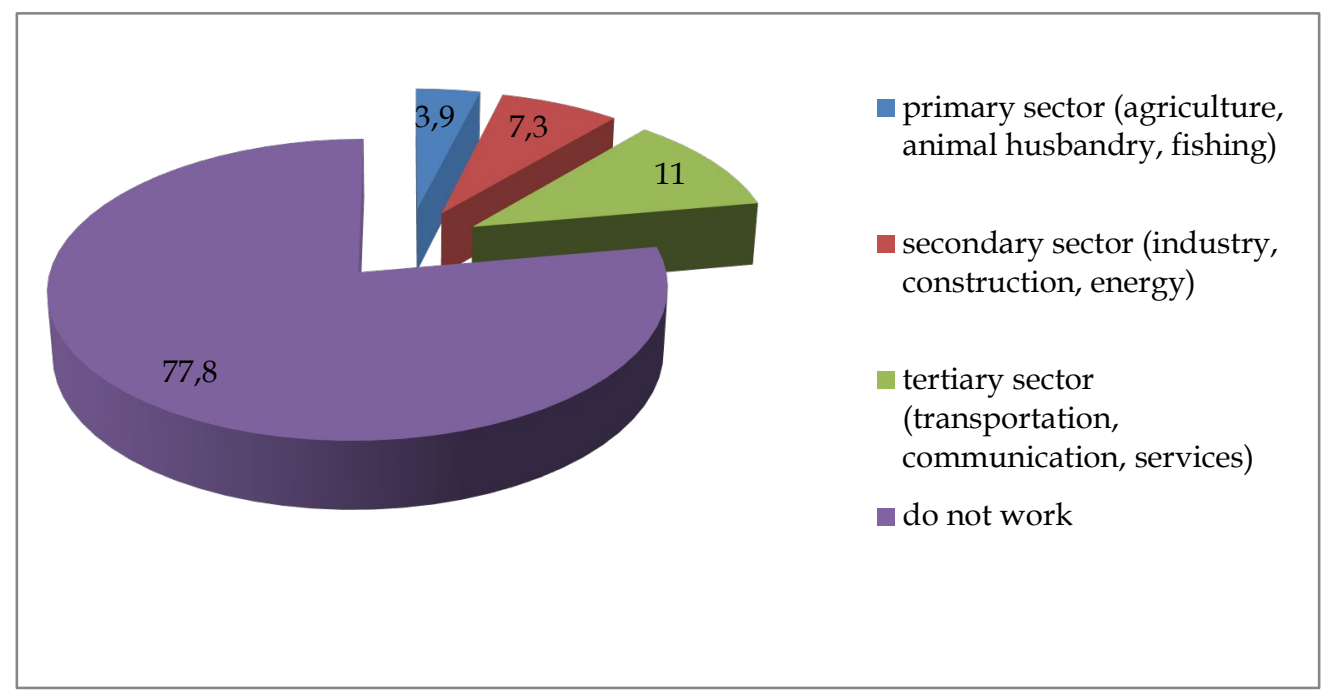

Source: Romanian Center for Comparative Migration Studies Survey (2018) 


\section{Discussion}

Compared to 2017, when the majority of immigrants came to Romania for studies, in the data set collected in 2018, the number of those who came to Romania to work exceeds that of those who came to study, representing the second most important reason of entry immediately after those who came for family reunion as their legal status (IGI 2018). This is a clear indicator that Romania is slowly emerging as an immigrant destination. This is a challenge that many destination countries have struggled to cope with in the last decades. Most EU member states are affected by the realities and challenges of integrating immigrant populations in the national workforce, and the consensus is that one important part of a successful integration process is a swift access to the labor market. As mentioned above, the outlining explanatory framework regarding the presence of immigrants in the least desirable forms of employment is market segmentation. The divide of labor market in different sub-markets which function by different rules depends to a large extent on the particular national context and has both social an economic implication (Piore 1979). The immigrant population is more vulnerable to this market dualism, being more prone to occupy the lower segment characterized by higher turnover and lower salaries, whereas the national population having easier access to the upper segment characterized by well-paid and stable jobs (Grubanov-Boskovic and Natale 2017).

In some EU member states segmentation is due to the contractual forms (Portugal and Spain), whereas in other countries (UK, Germany and Netherlands) the market divide is associated with gender differences and part-time work contacts (Deakin 2013). The future outlook of immigrants' integration on the labor market is strongly determined by the nature of employment opportunities that the immigrants have access to (GrubanovBoskovic and Natale 2017). Our findings indicate that a great proportion of the immigrants that are residing in Romania are medium and highly skilled and young, live in urban settings, and hold a job in the private sector. An important part of them tend to be excluded from accessing highly skilled jobs, are underpaid, face a much more precarious situation than the local population and have to face a cumbersome transition to better jobs. Moreover, we observed a certain polarization in terms of income and earning amongst 
immigrants in Romania. The respondents included in this research differ significantly in terms of income, a feature that can have a significant impact on their integration process and socio-economic status in the new host society. And subsequently it can accentuate the existent polarization and inequality that is widening on the Romanian labor market and society. All these issues, inherent to a dual labor market, are to some extent supporting the fact that there isn't a matter of lack of motivation to work but one of access to rewarding work places that are matching migrants' qualifications and skills.

In order to see improvements, we need to address the issue of access to better paid jobs. Ideally employment should match the candidate's qualifications when competing for a job with the national candidates. Knowing that the gaps in employment tend to decline over time - the longer an immigrant stays in a country, the higher his/her employment rate ()$^{2}-$ targeted measures for immigrant integration need to be taken for recently arrived third country nationals, thus increasing immigrants' economic benefits as well as improving social cohesion (OECD 2016). Improving labor market integration occupies a large part of G20 and EU economic strategies and the most promising proposed approaches to improve the abovementioned challenges are: better recognition procedures of foreign qualifications, building additional language skills, better matching between migrant's skills and labor market needs coupled with fighting discrimination and the employment of international labor standards (OECD 2016: 19).

Implementing all of these principles and objectives will require a considerably amount of expertise and resource and a complete rewiring of the Romanian institutions to this newly emerging situation. Moreover, the society and the state need to adapt to a new situation and a new social reality and develop a new narrative, where immigrants can find their place.

\footnotetext{
2 European Commission,'Action Plan On The Integration Of Third-Country Nationals.' Ec.europa.eu 2016. Web. 10 Dec. 2019. https://ec.europa.eu/home- affairs/sites/homeaffairs/files/what-wedo/policies/european-agenda-migration/backgroundinformation/docs/20160607/factsheet_action_plan_integration_third-country_nationals_en.pdf.
} 


\section{Bibliography}

Anderson, Bridget and Martin Ruhs. 2010. 'Migrant Workers: Who Needs them? A Framework for the Analysis of Shortages, Immigration, and Public Policy.' In Who Needs Migrant Workers? Labor Shortages, Immigration, and Public Policy, edited by Bridget Anderson and Martin Ruhs, 15-52. Oxford: Oxford University Press.

Andreß, Hans-Jürgen, and Romana Careja. 2018. 'Sampling migrants in six European countries: how to develop a comparative design?' Comparative Migration Studies 6 (33): 1-21.

Alderman, Liz. 2017. 'Europe's Thirst for Cheap Labor Fuels a Boom in Disposable Workers.' New York Times, Available at https://www.nytimes.com/2017/12/11/business/europe-laborrights.html?auth=login-google\&login=google.

Bauder, Harald. 2008. 'Citizenship as Capital: The Distinction of Migrant Labor.' Alternatives 33: 315-333.

Bernardi, Fabrizio, Garrido, Luis and Maria Miyar. 2011. 'The Recent Fast Upsurge of Immigrants in Spain and Their Employment Patterns and Occupational Attainment.'International Migration 49(1): 148-187.

Bertossi, Cristophe. 2008. 'The Regulation of Migration. A Global Challenge.' Politique étrangere vol. 5 Special Issue, CAIRN, Institut français des relations internationales, 189-202, Available at: https:/ / www.cairn.inforevue-politique-etrangere-2008-5-page189.htm.

Borjas, George J. 1985. “Assimilation, Changes in Cohort Quality, and the Earnings of Immigrants.' Journal of Labor Economics 3 (4): 463-489.

Bratsberg, Bernt, Raaum, Oddbjørn and Knut Røed. 2017. 'Immigrant labor market integration across admission classes.' Discussion Paper Series CDP 02/17. Centre for Research and Analysis of Migration (CREAM). London: University of College London.

Brochmann, Grete and Anniken Hagelund. 2011. 'Migrants in the Scandinavian Welfare State. The emergence of a social policy problem.' Nordic Journal of Migration Research 1 (1): 13-24, DOI: 10.2478/v10202-011-0003.

Brücker, Herbert, Hauptmann, Andreas, Jahn, Elke J. and Richard Upward. 2014. 'Migration and imperfect labor markets: Theory and crosscountry evidence from the Denmark, Germany and the UK.' European Economic Review 66: 205-225. 
Büchel, Felix and Joachim R. Frick. 2005. 'Immigrants' economic performance across Europe - does immigration policy matter?' Population Research and Policy Review 24 (2): 175-212.

Burean, Toma. 2017. 'Locuire.' In Indexul Integrării Imigranților În România, edited by Anatolie Coșciug, Ionela Răcătău, Gabriel Bădescu, Toma Burean, Georgiana Găvruș, Carmen Greab, Bogdan Radu, Ovidiu Oltean, Călin Rus and Andreea Vornicu, 66-76. Centrul pentru Studiul Comparat al Migrației: Cluj-Napoca.

Careja, Romana and Patrick Bevelander. 2018. 'Using population registers for migration and integration research: examples from Denmark and Sweden', Comparative Migration Studies 6 (19): 1-27.

Castles, Stephens, Davidson, Alastair, Citizenship and Migration. Globalization and the Politics of Belonging. Houndmills, Basingstoke and London: Macmillan Press, 2000.

Coșciug, Anatolie, Răcătău, Ionela, Bădescu, Gabriel, Burean, Toma, Găvruș, Georgiana, Greab, Carmen, Radu, Bogdan, Oltean, Ovidiu, Rus, Călin and Andreea Vornicu. 2017. 'Indexul Integrării Imigranților În România.' Centrul pentru Studiul Comparat al Migrației: ClujNapoca.

Coșciug, Anatolie, Burean, Toma, Greab, Carmen, Radu, Bogdan, Oltean, Ovidiu and Andreea Vornicu. forthcoming. "Indexul Integrării Imigranților În România.'Centrul pentru Studiul Comparat al Migrației: Cluj-Napoca.

Deakin, Simon. 2013. 'Addressing labour market segmentation: the role of labour law.' Working Paper No. 52, International Labour Office, Governance and Tripartism Department. - Geneva: ILO, https://www.ilo.org/wcmsp5/groups/public/---ed_dialogue/--dialogue/documents/publication/wcms_223702.pdf.

Derscariu, Radu and Mihaela Vechiu. 2018. 'Importul forței de muncă în România - modificări legislative recente care sprijină procesul de angajare a străinilor.' Available at: https://www2.deloitte.com/ro/ro/pages/tax/articles/importulfortei-de-munca-in-romania-modificari-legislative-recente-caresprijina-procesul-de-angajare-a-strainilor.html.html.

Dickens, Williams T. and Kevin Lang. 1988. 'The Reemergence of the

Segmented Labor Market Theory.' The American Economic Review 78 (2): 129134.

Drbohlav, Dušan. 2012. 'Patterns of Immigration in the Czech Republic, Hungary and Poland. A Comparative Perspective.' In European Immigrations. Trends, Structures and Policy Implications, edited by Marek 
Okólski, 179-209. Amsterdam: Amsterdam University Press (IMISCOE).

Drbohlav, Dušan, Hárs, Ágnes and Izabela Grabowska-Lusińska. 2009. "Experiencing Immigration: Comparative Analysis of the Czech Republic, Hungary and Poland.'IDEA Working Papers No. 14. IDEA. Dustmann, Christian and Francesca Fabbri. 2005. 'Immigrants in the British labour market.' The Economic Journal 115: 324-341.

Dustmann, Christian and Tommaso Frattini. (2012). 'Immigration: The European Experience'. Norface Migration Discussion Paper No. 201201.

Duvander, Ann-Zofie. 2001. 'Do country specific skills lead to improved labor market positions? An analysis of unemployment and labor market returns to education among immigrants in Sweden.' Work and Occupations 28 (2): 210-233.

Ersanilli, Evelyn and Ruud Koopmans. 2011. 'Do Migrant Integration Policies Matter? A Three-Country Comparison among Turkish Immigrants.' West European Politics 34 (2): 208-234.

European Commission. 2016. 'Action Plan on the Integration of ThirdCountry Nationals.' Available at: https://ec.europa.eu/homeaffairs/sites/homeaffairs/files/what-we-do/policies/europeanagenda-migration/backgroundinformation/docs/20160607/factsheet_action_plan_integration_third -country_nationals_en.pdf.

Eurostat. 2016. European Labour Force Survey. Available at: http://ec.europa.eu/Eurostat/web/microdata/european-unionlabour-force-survey.

Eurostat. 2015. Immigration in the EU, Available at: https://ec.europa.eu/home-affairs/sites/homeaffairs/files/elibrary/docs/infographics/immigration/migration-in-euinfographic_en.pdf.

Eurostat. 2011. 'Migrants in Europe. A statistical portrait of the first and second generation.' Eurostat Statistical Books. Luxemburg: Publications Office of the European Union.

Florea, Adina. 2019. 'România e în plin boom de muncitori asiatici. Dar cinesunt ei?.' Inclusiv.ro, Available at: https://inclusiv.ro/suntem-inplin-boom-de-muncitori-asiatici/.

Gryzmała-Kazłowska, Aleksandra. 2015. "The role of different forms of bridging capital for immigrant adaptation and upward mobility. The case of Ukrainian and Vietnamese immigrants settled in Poland.' Ethnicites 15(3): 460-490. DOI: 10.1177/1468796813518314. 
Grubanov-Boskovic, Sara and Fabrizio Natale. 2017. 'Migration in a segmented labour market.' JRC Technical Reports, EUR 28731, 2017, ISBN 978-92-79-71867-0, doi: 10.2760/213154, JRC 107601.

Herzog-Punzenberger, Barbara. 2003. 'Ethnic Segmentation in School and Labor Market - 40 Year Legacy of Austrian Guestworker Policy.' International Migration Review 37 (4): 1120-1144.

Górny, Agata, Grabowska-Lusińska, Izabela, Lesińska, Magdalena and Marek Okólski. 2009. 'Poland: becoming a country of sustained immigration.' IDEA Working Papers. IDEA.

Granato, Nadia. 2014. 'A Work in Progress. Prospects for Upward Mobility among New Immigrants in Germany.' A Series on the Labor Market Integration of New Arrivals in Europe: Employment Trajectories. Washington DC: Migration Policy Institute and International Labor Organization.

Inspectoratul General pentru Imigrări. 2019. 'Avizele de angajre/detașare a cetățenilor străini s-au suplimentat cu 1000'. IGI - Inspectoratul General pentru Imigrari. [online] Available at: http:/ /igi.mai.gov.ro/ro/comunicat/avizele-deangajaredeta $\%$ C8\%99are-cet $\%$ C4\% 83\% C8\%9Benilor-str $\%$ C4\%83ini-sau-suplimentat-cu-10000.

Inspectoratul General pentru Imigrări. 2018. 'Numărul Cetățenilor Străini (BPI, RTT și iEU) Stabiliți Legal în România la 31.12.2017.' Data provided by Biroul Date Statistice a Inspectoratului General pentru Imigrări din România.

Inspectoratul General pentru Imigrări. 2017. Numărul cetățenilor străini (BP şi RTT) care au obținut drept de şedere pe teritoriul României, primul permis şi stocul total, în 2016 şi 2017 (defalcat pe regiuni). Data provided by Direcția Management Strategic a Inspectoratului General pentru Imigrări din România.

Institutul Național de Cercetări Economice and KPMG. 2019. Analiza cantitativă și calitativă a pieței muncii în România. Studiu realizat pentru Confederația Patronală Concordia. Ianuarie 2019, Available at: https://s3-eu-west-1.amazonaws.com/bkpsavastvps/_websites/fppg.ro/03+\%5BConcordia\%5D+Studiu+piata +muncii_varianta+scurta+20190110.pdf.

Institutul Național de Statistică. 2018. 'Câștigul salarial mediu brut pe economie a fost în luna decembrie 2017 de 3662 lei', Press release 32 (9), February, Available at: http://www.insse.ro/cms/ro/comunicate-de-presa-view. 
Institutul Național de Statistică. 2018. Câştiguri salariale, serie lunară, Available at: http://www.insse.ro/cms/ro/content/c\%C3\%A2\%C8\%99tigurisalariale-din-1991-serie-lunar\%C4\%83.

Janská, Eva, Čermak, Zdenĕk and Richard Wright. 2014. 'New Immigrant Destinations in a New Country of Immigration: Settlement Patterns of Non-natives in the Czech Republic.' Population, Space and Place 20: 680693.

Joppke, Christian. 2007. 'Transformation of Immigrant Integration: Civic Integration and Antidiscrimination in the Netherlands, France and Germany.' World Politics 59 (2): 243-273.

Kogan, Irena. 2011. “New Immigrants, Old Disadvantage Patterns? Labor

Market Integration of Recent Immigrants into Germany.' International Migration 49(1): 91-117.

Kogan, Irena. 2007. Working through barriers: host country institutions and immigrant labour market performance in Europe. Dordrecht: Springer.

Koopmans, Ruud. 2010. 'Trade-Offs between Equality and Difference: Immigrant Integration, Multiculturalism and the Welfare State in Cross-National Perspective.' Journal of Ethnic and Migration Studies 36 (1): 1-26.

Lodovici, Manuela S. 2010. Making a Success of Integrating Immigrants in the Labor Market, Discussion Paper November 2010, Instituto per la Ricerca Sociale, Roma.

Martin, Roderick and Ana-Maria Martin-Cristescu. 2004. 'Consolidating segmentation: post-Socialist employment relations in Central and Eastern Europe.' Industrial Relations Journals 35 (6): 629-646.

Massey, Douglas S., Alarcón, Rafael, Durand, Jorge and Humberto González, Humberto. 1990. Return to Aztlan. The Social Process of International Migration from Western Mexico. Berkeley, California: University of California Press.

Mau, Steffen and Christoph Burkhardt. 2009. 'Migration and welfare state solidarity in Western Europe.' Journal of European Social Policy 19 (3): 213-229, DOI: 10.1177/0958928709104737 http:/ / esp.sagepub.com.

Migration Data Portal \& UNDESA. 2018. Immigration and Emigration Statistics: International Migrant Stocks, Available at: https:/ / migrationdataportal.org/?i=stock_abs_\&t=2019\&m=1\&rm49 $=150$.

Migration Data Portal \& UNDESA. 2017. Immigration and Emigration Statistics: International Migrant Stocks, Available at: https:/ / migrationdataportal.org/themes/international-migrantstocks. 
Morissens, Ann and Diane Sainsbury. 2005. 'Migrants' Social Rights, Ethnicity and Welfare Regimes.' Journal of Social Policy 34 (4): 637-660.

OECD. 2019. Self-employment rate (indicator). DOI: 10.1787/fb58715e-en.

OECD. 2018. Settling In 2018. Main Indicators of Immigrant Integration. OECD and European Commission, Available at https:/ / www.oecd.org/els/mig/Main-Indicators-of-ImmigrantIntegration.pdf.

OECD. 2016. Towards a Framework for Fair and Effective Integration of Migrants into the Labor Market, Available at https://www.ilo.org/wcmsp5/groups/public/---dgreports/--inst/documents/publication/wcms_559139.pdf.

OECD. 2015. Indicators of Immigrant Integration 2015. Settling In. Available at: http:/ / www.oecd-ilibrary.org/social-issues-migrationhealth/indicators-of-immigrant-integration-2015-settlingin_9789264234024-en.

Pavlínek, Petr, Domanski, Boleslaw and Robert Guzik. 2009. 'Industrial Upgrading Through Foreign Direct Investment in Central European Automotive Manufacturing.' European Urban and Regional Studies 16 (1): 43-63.

Pawlak, Mikołaj. 2015. 'Research-Policy Dialogues in Poland.' In Integrating Immigrants in Europe: Research-Policy Dialogues, edited by Peter Scholten, Han Entzinger, Rinus Penninx, Stijn Verbeek, 253-273. Amsterdam: Amsterdam University Press (IMISCOE).

Phalet, Karen and Marc Swyngedouw. 2003. 'Measuring immigrant integration: the case of Belgium.' Studi Migrazione/Migration Studies 40 (152): 773-803.

Perugini, Cristiano and Fabrizio Pompei. 2016. “Employment protection and wage inequality within education groups in Europe.' Journal of Policy Modeling 38 (5): 810-836.

Piore, Michael. 1979. Birds of Passage. Migrant Labor and Industrial Societies. Cambridge: Cambridge University Press.

Portes, Alejandro and Rubén G. Rumbaut. 2006. Immigrant America. A Portrait (3rd edition). Berkeley, California: University of California Press.

Portes, Alejandro, Castells, Manuel and Lauren A. Benton (Eds.). 1989. The Informal Economy. Studies in Advanced and Less Developed Countries. Baltimore and London: The John Hopkins University Press.

Poșirca, Ovidiu. 2017. 'Analysis. Firms struggle to find workers on tight labor market in Romania' Business Review, Available at: http://businessreview.eu/news/analysis-firms-struggle-to-find-workers-on-tightlabor-market-in-romania-149954. 
Reich, Michael, Gordon, David M. and Richard C. Edwards. 1973. 'A Theory of Labor Market Segmentation.' The American Economic Review 63 (2): 359-365.

Reitz, Jefferey G. 1998. 'Warmth of the Welcome: The Social Causes of Economic Success for Immigrants in Different Nations and Cities.' Boulder, CO: Westview Press.

Simonsen, Kristina B. 2017. 'Does citizenship always further immigrants' feeling of belonging to the host nation? A study of policies and public attitudes in 14 Western democracies', Comparative Migration Studies 5 (3) 2017: 1-17.

Stepick, Alex. 1989. 'Miami's two informal sectors' In The informal economy: Studies in advanced and less developed countries, edited by Alejandro Portes, Manuel Castells and Lauren A. Benton 1989, 111-131. Baltimore and London: The John Hopkins University Press.

Wilson, Kenneth L. and Alejandro Portes. 1980. 'Immigrant Enclaves. An Analysis of the Labor Market Experience of Cubans in Miami.' American Journal of Sociology 86 (2): 295-319. DOI: 10.1086/227240. 